\title{
The Effect of Indonesian Government's Debt to the US and Greece on Composite Stock Price Index in ASEAN-5 and Australia
}

\author{
Nugroho Saputro* \\ Faculty of Economics and Business, Universitas Sebelas Maret, Indonesia
}

\begin{abstract}
Global economic crisis has become a nightmare for other countries, when the crisis is originated from a multipower country. A financial crisis that hit European countries (Greece) in 2010 and the United States (US) in 2011 can be categorized as financial crisis that caused by high state's debt that leads to default. The response to financial crisis is reflected in capital market players' reaction, where other countries will respond to a particular endemic financial crisis. The objectives of this research are (1). Analyze the Impulse Response Function (IRF) of the Composite Stock Price Index of the US on Composite Stock Price Index in Indonesia, Malaysia, Singapore, Vietnam, Thailand and Australia. (2). Analyze the Impulse Response Function (IRF) of the Composite Stock Price Index of Greece on the Composite Stock Price Index in Indonesia, Malaysia, Singapore, Vietnam, Thailand and Australia. (3). Analyze the Forecasting Error Variance Decomposition (FEVD) of the Composite Stock Price Index of Indonesia on the Composite Stock Price Index of Malaysia, Singapore, Vietnam, Thailand and Australia. The analysis will be conducted using VAR (Vector Auto regression). The result shows that all variables are responded to the financial crisis that happened in Greece and the US. This is reflected by the shocks created by the financial crisis in ASEAN- 5 countries and Australia. On the other hand, the Composite Stock Price Index of Indonesia is also affected by Malaysia and Singapore.
\end{abstract}

Keywords: Global Financial Crisis, Government’s Debt, ASEAN-5, Australia, Stock Price Index.

\section{Introduction}

A ratification of debt agreement by Barack Obama on 2nd August 2011, allows for fundamental transformation in world economics. The agreement between the Government of the United States (US) and the United States Congress, on debt value triggering a reaction from global exchange player. The US debt is recorded at US\$14.3 Trillion, with 30 percent of it comes from foreign investor, and the other 70 percent of domestic investor. The quantity of debt owned by the Government of the United States has wide effect due to the US Gross Domestic Product (GDP) at US\$15 Trillion. This value constitute 25 percent of total world GDP, which amounted to US\$60 Trillion (Kontan, 2011).

Decreased or low Gross Domestic Product (GDP) has a negative effect on economic growth. The effect shown on the decrease of economic growth. Slow economic growth has various effect on the society life. The effect of economics fluctuation can be seen in a country unstable condition, which known as financial crisis. Bloomberg (2011) is quoting several statements of analyst such as, 'the economic condition is on the edge of a cliff' (Martin Feldstein, Harvard University) and Ben Bernanke (Chairman Federal Reserve) in one of his speech states that 'right at this moment, the possibility of the US fall into recession is only reach 50 percent'. Those statements indicate a recession that may occur to the US economy, which will affect world economic condition. The US recession in 2011, can be 
viewed from its credit rating released by Standard and Poor that changed from $A A A$ to $A A+$ (Bloomberg, 2011).

Prior to the US crisis, several European countries has faced uncertain economic condition due to the crisis in Greece and followed with the crisis in Italy. The source of the crisis is mainly because of the huge debt of the government in those countries. Before the shock of the US crisis in 2008 subsided, the capital market got hit by other crisis in European countries and the US as a result of government's debt.

The indicators in capital market will respond quickly to a recession that take places in the US and Europe. This response is a real manifestation of the contagion effect of a crisis from one country to another country as the effect of global financial market integration. The contagion effect of a crisis is an uncontrollable side effect of globalization. The globalization with an overly free market system without government intervention, will create huge income gap between high social class (rich countries) and the low social class (poor countries). Market system globalization, generally, is based on market mechanism and invisible hand.

In history, the crisis that hit Indonesia is the result of contagion effect from a crisis that happened in other countries, such as: the 1998 monetary crisis as an effect of Thailand crisis, and 2008 financial crisis as an effect of the US subprime mortgage tragedy. The 2011 crisis in the US was caused by a high governmental debt, which different from the 2008 crisis that was started from the private sector. Subprime mortgage in 2008 resulted in the collapse of housing loans companies. The impact of the 2008 financial crisis also responded by global capital market, including Indonesia. During the 2008, the authority of Indonesian capital market (BAPEPAM and the Finance Department of Indonesia) had to suspend the capital market activities.

Capital market is one of substantial aspects in global economy and a booster for national economy. There are many industries and companies that use capital market as a media to get investment and to strengthen its financial position. A price fluctuation in capital market can be used as an indicator to observe crisis. Crisis anticipation is needed to determine the policy needed and to identify the indicators of crisis, thus the level of welfare could be maintained (Bappenas, 2011).

The objective of this paper is to analyze the correlation between the stock price index in the US and Europe (Greece) on the stock price index in Indonesia, Malaysia, Singapore, and Australia during the global financial crisis in 2011. This paper is also aimed to analyze the response of stock price index in the US and Europe (Greece) on the shock that happened in Indonesia, Malaysian, Singapore, and Australian stock price index during global financial crisis period in 2011. Moreover, the paper analyze the comparison of the role of stock price index in Indonesia, Malaysia, Singapore, and Australia in explaining the variation of stock price index in the US and Europe (Greece) during the global financial crisis period in 2011.

This research is expected to be a guidelines for a policy making related to financial stability by the government and this research is expected to be useful for the investors to make a decision in investing in the capital market sector.

\section{Review of related literature}

The topic of financial crisis has been widely discussed. Laeven and Tong (2010) examine about the correlation between the US monetary policies on global stock price. The research uses a data from 20.121 companies in 44 countries, including 227 companies listed in Indonesia Stock Exchange (IDX) during 1990 to 2008. Laeven and Tong (2010) uses regression and panel to analyze their research. They find that global stock price will respond to the change in the US interest change. This indicated by the decrease or increase in stock price along with a tightening or relaxation of the US monetary policy. This effect is more evident in the sectors that depend on external funding and in a country with a capital market that integrated with global capital market.

Dash and Mallick (2010) conduct a study which aims to find out if there is a contagious effect of the global financial crisis that started from the United States on the stock market in India. They use Dynamic Conditional Correlation (DCC) multivariate GARCH Engle to test the relationship between stock returns in BSE (Bombay Stock Exchange) and NASDAQ. The research find that there is a significant increase in the average value of correlation coefficient between market condition during and 
before crisis. Therefore, it can be concluded that there is a connection between global financial crisis and India stock market.

In line with the research of Dash and Mallick (2010), another research is conducted by Adamu, (2010), he investigates the effect of global financial crisis on Nigeria economics condition. However, the research is more focused on qualitative analysis of several economics aspects such as Foreign Direct Investment (FDI) and stock investment, the trend of oil price decline, aid, and commercial loan. The result show that financial crisis leads to the decline in commodities price, export quantity, portfolio, and lower FDI.

Another researcher, Zhang et al. (2009), examine about the effect of the US credit crisis on Asia Pacific economic condition. The research uses data from several countries such as Japan, South Korea, China, Indonesia, Malaysia, Singapore, Thailand, Philippines, Australia, and New Zealand. The data is analyzed using a methodology that is developed by International Monetary Fund (IMF) namely Global Integrated Monetary and Fiscal (GIMF). The GIMF is developed further by Hong Kong's authority into eight regions version, which aims to uncover heterogenic economics structure in East Asia countries. The result shows that the credit crisis in the US has a huge effect on Asia Pacific economic condition through financial and trade connection.

\section{Theoretical Framework}

\section{Capital Flight}

Capital flight is related with a condition with high uncertainty and risk, in term of economic and non-economic. This condition motivate investors to bring their fund abroad, in order to avoid losses if they keep their fund in the country. Capital flight happens because of investors' fear of assets loss due to domestic currency depreciation, government's default, sudden change in capital management policy and money and capital market policy, or fiscal policy that can cause great loss to capital owners (Lensink et al., 2000).

A more moderate definition is delivered by Mankiw (2006) who define net capital outflow as the total debt provided by domestic investor to other countries (abroad) deducted by debt provided by international investor into the country. Mankiw emphasizes on the difference in capital outflows minus capital inflows. Other researcher, Salvatore (1996) defines capital flight as transfer of funds overseas by citizen or domestic companies to obtain the largest or safest income or interest, without considering whether their country need the fund or not.

Schineller (1997) defines capital flight as short-term capital outflow to foreign countries whether recorder or not, which is speculative, by non-bank sector. Capital flight is measured by adding shortterm capital flows with net error and omission on the balance of payments. Capital outflow is used to measure the recorded component, while net error and omission is to measure the unrecorded component. Capital flight also refers to the reduction of reserve fund due to devaluation issues, because the debit value on the balance of payments (reduction in assets) is the same with private capital outflow (Krugman and Obstfeld, 1999).

\section{Cross-country capital flows}

Appleyard and Jr (1995) propose several reason for cross-country capital investment, A company will invest its capital across countries in response to the growing and expanding market. This hypothesis is supported by an empirical study that states if there is a positive relationship between the Gross Domestic Product (GDP) of beneficiary country and the quantity of incoming FDI. Along with the above reason, service and processing production from developed countries will increase their service in order to meet the demand, which is growing as a result of increased per capita income in the country of destination. This is also the reason for developed countries to invest their capital to other countries. Another reason is the effort to ensure access to basic material and the amount of material reserves, thus it encourages developed countries to invest their capital into the targeted country. Differences in tariff and non-tariff barriers in host country may also be the reason why capital inflows occur. Low wages is another consideration for cross-country investment. Huge human resource in developing countries, which leads to low wages, has become the target for investment especially in the production of goods with labor-intensive technology. Another strong consideration is the needs to 
ensure and strengthen the market share, while multinational companies also offer similar product to the market. Risk diversification is another consideration for investor in investing their fund to other countries. A higher return for cross-country investment because of the low competitiveness of local companies against foreign companies in the country. Such condition can happened due to the management's superiority and skills possessed by foreign companies compared to the domestic companies. International capital flow theory states that capital will flow to the most profitable place (country). Under such circumstance global output will be maximum.

Table 3. Financial Crisis with Global Impact: 1980-2008

\begin{tabular}{|c|c|c|c|}
\hline $\begin{array}{c}\text { Origin of Shock, } \\
\text { Country, and Date of } \\
\text { Event }\end{array}$ & $\begin{array}{l}\text { External Shock } \\
\text { Characteristics }\end{array}$ & Spreading Mechanism & Affected Countries \\
\hline 1 & 2 & 3 & 4 \\
\hline $\begin{array}{l}12 \text { August, } 1982, \\
\text { Mexico experienced a } \\
\text { default of its foreign } \\
\text { debt from its banking } \\
\text { sector. Until December } \\
\text { of the same year, the } \\
\text { exchange rates of Peso } \\
\text { had been depreciated } \\
\text { for } 100 \text { percent. }\end{array}$ & $\begin{array}{l}\text { During } 1980-1985, \\
\text { commodity prices } \\
\text { crashed for } 31 \text { percent. } \\
\text { US short-term interest } \\
\text { rates increased for } 7 \\
\text { percent, which marked } \\
\text { the highest level since } \\
\text { Great Depression. }\end{array}$ & $\begin{array}{l}\text { Excessive funding to } \\
\text { Mexico from the US } \\
\text { banking, diversion } \\
\text { from developing } \\
\text { country. }\end{array}$ & $\begin{array}{l}\text { All countries in Latin } \\
\text { America region } \\
\text { experience default, } \\
\text { except Chile, Colombia } \\
\text { and Costa Rika. }\end{array}$ \\
\hline $\begin{array}{l}\text { In September } 1992 \text {, } \\
\text { Finland money market } \\
\text { changed to floating rate } \\
\text { which leads to } \\
\text { exchange rate system } \\
\text { crisis (Exchange Rate } \\
\text { Mechanism (ERM)). }\end{array}$ & $\begin{array}{l}\text { High interest rate in } \\
\text { Germany. Rejection } \\
\text { from Denmark against } \\
\text { Maastricht Treaty. }\end{array}$ & Hedge Funds. & $\begin{array}{l}\text { All countries with } \\
\text { European Monetary } \\
\text { System except } \\
\text { Germany. }\end{array}$ \\
\hline $\begin{array}{l}\text { Mechanism (ERM)). } \\
\text { In } 20 \text { December } 1994 \text {, } \\
\text { Mexico announced a } \\
\text { devaluation to Peso at } \\
15 \text { percent. This leads } \\
\text { to trust crisis, and later } \\
\text { in March } 15 \text { th } 1995 \text {, } \\
\text { Peso got devaluated at } \\
100 \text { percent rate. }\end{array}$ & $\begin{array}{l}\text { Starting on } 1994 \text { the US } \\
\text { Federal Reserve, } \\
\text { increase the interest rate } \\
\text { (federal funds rate) for } \\
2.5 \text { percent. }\end{array}$ & $\begin{array}{l}\text { There was a huge sales } \\
\text { in mutual fund in } \\
\text { Latin America } \\
\text { countries such as } \\
\text { Argentina and Brazil. } \\
\text { Uncertainties in } \\
\text { banking condition and } \\
\text { capital flight in } \\
\text { Argentina. }\end{array}$ & $\begin{array}{l}\text { Argentina is the most } \\
\text { suffering country with } \\
\text { almost } 20 \text { percent } \\
\text { deposit losses in early } \\
1995 \text {, while Brazil is } \\
\text { second in list. }\end{array}$ \\
\hline $\begin{array}{l}\text { In } 2 \text { July } 1997 \text {, } \\
\text { Thailand announced } \\
\text { that Baht will develop } \\
\text { its exchange rates. In } \\
\text { January } 1998 \text {, Baht is } \\
\text { depreciated for } 113 \\
\text { percent. }\end{array}$ & $\begin{array}{l}\text { Yen is depreciated for } \\
51 \text { percent on US } \\
\text { Dollar during April } \\
\text { 1995-April 1997. The } \\
\text { relation between Asian } \\
\text { currencies with US } \\
\text { Dollar created } \\
\text { appreciation on Yen. }\end{array}$ & $\begin{array}{l}\text { Japanese banking } \\
\text { provide loans to } \\
\text { Thailand, which leads } \\
\text { to withdrawal from } \\
\text { Asian countries. } \\
\text { European banks also } \\
\text { widraw their fund } \\
\text { from Korea due to the } \\
\text { effect. }\end{array}$ & $\begin{array}{l}\text { Indonesia, Korea, } \\
\text { Malaysia, and } \\
\text { Philippines are the most } \\
\text { severely affected by the } \\
\text { crisis. Singapore's } \\
\text { financial market and } \\
\text { Hong Kong also caught } \\
\text { in shock. }\end{array}$ \\
\hline $\begin{array}{c}\text { Origin of Shock, } \\
\text { Country, and Date of } \\
\text { Event }\end{array}$ & $\begin{array}{l}\text { External Shock } \\
\text { Characteristics }\end{array}$ & Spreading Mechanism & Affected Countries \\
\hline 1 & 2 & 3 & 4 \\
\hline
\end{tabular}




In 18 August 1998,
Russia experienced a
default on Domestic
Bonds. Between July
1998 and January 1999 ,
Ruble is depreciated for
262 percent. On 2
September 1998,
LTCM went bankrupt.

In 13 January, 1999, Brazil did a devaluation and develop its currency in 1 February. Between January and early February, there was a depreciation at 70 percent.

22 February 2001, Turkey devaluate and develop its currency (Lira).

In 23 December 2001 The President of Argentina announced that there is a possibility of default.

In the end of 2007, there was a Subprime Mortgage crisis, where bank provide credits for various housing loans.

Housing loans securities emerge due to easy money policy that implemented by Alan Greenspan during 2001A semi-controlled exchange policy that was adopted in July 1994, which aims to stabilize inflation is abandoned.

Facing a substantive financial needs, in the end of November 2000, a rumor about the withdrawal of foreign debt in Turkish banks has resulted in a capital flight outflow, thus within an overnight the interest rate increased up to 2000 percent. Following several wave of capital flight and bank deposit flight, on the 1st December 2001 capital control policy is established.

The impact of the crisis was felt in the world oil price which continues to increase, even reaching 110 US dollars per barrel. In 10 October 2008 the world's exchanges are falling.

\author{
Margin call and hedge \\ funds are triggered by \\ sales in developing \\ countries and other \\ highly profitable \\ markets. Difficulty in \\ differentiating \\ between the \\ contagious effect from
}

Russia and fear of

LTCM bankruptcy.

There was increased volatility in several major capital market, while the spread of Argentina get wider. The capital market in Argentina and Chile were competing each other for several days.

The banking deposit in Uruguay reached more than 30 percent, because the banks in Argentina received deposit from Uruguay banks. There was a significant effect on economics activities (trades and tourism) in Uruguay.

There was a volatility in several capital market in the world.

All US trading partners felt a negative effect, some sectors with foreign capital tend to move its location to other countries. 2003. The effect of this crisis was felt in 2008.

Source: IMF, International Financial Statistics, Reinhart, Rogoff and Savesteno as quoted in Prasetyantoko (2008:26-18) with modification. 


\section{Portfolio theory}

The theory of portfolio choice that affect asset are Mishkin (2007) wealth, when a person's wealth increases, thus he/she will have more resource to acquire assets, expected return refers to the rate of return expected by acquiring certain assets, risk is the level of uncertainty that related to asset in relative terms to other assets, liquidity refers to how quickly and easily an asset is converted into cash. The history of crisis

Prasetyantoko (2008) defines crisis as financial instability, a drastic changes in financial assets price. The financial assets are shares (stocks), bonds, mortgages, futures, as well as various securities and other derivative products. Financial crisis is not a new phenomenon, financial crisis has happened in several countries such as explicitly displayed in Table 3.

Table 4. The US Crisis in 2008

\begin{tabular}{|l|}
\hline April -----> \\
\hline New Century \\
Financial's housing \\
finance company \\
went bankrupt
\end{tabular}

28 August ----->
Sachsen
Landesbank in
Germany collapsed
due to investment in
housing loans

3 September ----->

17 February ----->

17 March ----->

German financial institutions (IKB) admit investment in subprime mortgages is lost up to USD 1

The British

\section{nationalized}

Northern Rock

Bear Stearns

collapsed and was

bought by JP

Morgan Chase

with an American

government

guarantee worth

USD 30 billion

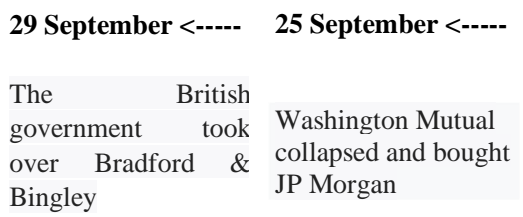

16 September <-----

15 September <-----

5 September <-----

Fed injects AIG for

USD 85 billion

Lehman Brothers

Fannie Mae and

Freddie Mac were went bankrupt taken over by the

American

government

10 Oktober
Stock market
indexes were falling
again

\begin{tabular}{l} 
8 Oktober <----- \\
$\begin{array}{l}\text { Britain prepares } £ \\
50 \text { billion (US } \$ 87 \\
\text { billion) bailout }\end{array}$ \\
\hline
\end{tabular}
6 Oktober <-----
Germany launches USD 68 billion to support Hypo Real
Estate

3 Oktober <-----
The American
Congress passed a $\$$
700 billion bailout
program

30 September

France, Belgium, Luxembourg work together to save

Dexia

Source: Tempo (2008) in Minister of Information (Menkoinfo), 2008.

The movement or spread of financial turmoil, which started from a superpower country, has a huge impact on some countries. Table 3 and Table 4 illustrate the respond to crisis (financial turmoil) as a series of an economics degradation process. The effect of the crisis could take days, months, or years to get noticed.

\section{Research Method}

\section{Data source and type}

This research uses secondary data, which consist of Composite stock price data (US Dow Jones Index-DJI and Greece Athens Stock Exchange-ATHE); The composite stock price data in five ASEAN countries (1). Indonesia (JKSE), (2). Malaysia (KLSE), (3). Singapura (STI), (4). Thailand (SET), and (5). Vietnam (VHINDEX), and Australia (AORD). The observation period is starting from the Greece default, April 2010 to December 2011.

\section{Vector Auto regression (VAR)}

VAR is a continuation of monetarist criticism of the Keynesian. Some characteristics of VAR show an alignment to monetarist, the first VAR method is developed on the basis of criticism on the previous large models. Secondly, VAR offers a simple model with minimalist amount of variable, with the independent variable is lag of all endogenous variables. Thirdly, VAR is a continuation of causality 
test and, VAR characteristic cannot be separated from Granger's causality test characteristic such as, focused on identity study. Most of the identity can be found in monetarist reasoning such as the quantity of money theory ( $\mathrm{MV}=\mathrm{PT})$, inflation and interest rate correlation $(\mathrm{i}=\mathrm{r}+\mathrm{p})$, and other identities (Thomas, 1997).

VAR is usually adopted for projecting a system of time-dependent variable and to analyze the dynamic effect of interference factor within the variable system. Basically, VAR analysis is equivalent with simultaneous equation, because in VAR analysis the endogenous variables are simultaneously considered in a model. Different with ordinary simultaneous equation, each variable in VAR analysis, besides it is explained by its value in the past, it also explained by other endogenous variables' value in the past. The VAR model is showed in the following equation (Gujarati, 2004).

$y_{\mathrm{t}}=\mathrm{a}_{10}+\mathrm{a}_{11} \mathrm{y}_{\mathrm{t}-1}+\mathrm{a}_{12} \mathrm{z}_{\mathrm{t}-1}+\mathrm{e}_{1 \mathrm{t}}$

$\mathrm{z}_{\mathrm{t}}=\mathrm{a}_{20}+\mathrm{a}_{21} \mathrm{y}_{\mathrm{t}-1}+\mathrm{a}_{22} \mathrm{z}_{\mathrm{t}-1}+\mathrm{e}_{2 \mathrm{t}}$

Changes in $e_{1 t}$ will affect the changes in value of $y$. The changes will affect all future value of $y$ and $z$, since the variable of $y$ and lag variable $\left(y_{t-1}\right)$ are included in both equation. When there is an innovation, $e_{1 t}$ and $e_{2 t}$ are not correlated, interpretation will apply continuously. The term $e_{1 t}$ denotes innovation for $y$ and $e_{2 t}$ denotes innovation for $z$. The notion of $e_{2 t}$ is used to measure the effect of the deviation standard of a monetary policy implementation shock on the current and future value of variable of $y$ and $\mathrm{z}$, which is observed in this research.

Enders (2004) illustrates the establishment of standard VAR model, started from simple bivariate equation as follows:

$y_{t}=b_{10}-b_{12} z_{t}+\gamma^{11} y_{t-1}+\gamma_{12 z t-1}+\varepsilon_{y t}$
$z_{t}=b_{20}-b_{21} y_{t}+\gamma_{21} y_{t-1}+\gamma_{22 z t-1}+\varepsilon_{y t}$

The first step in creating standard VAR model formulation is by transforming the equations 3 and 4. The transformation can be conducted using algebra matrix, thus new equations are obtained as follows:

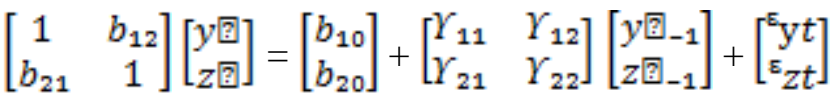

or

$\mathrm{B} \chi_{t}=\Gamma_{0}+\Gamma_{1} \chi_{t-1}+\epsilon_{t}$

where

$B=\left[\begin{array}{cc}1 & b_{12} \\ b_{21} & 1\end{array}\right] \quad X_{t}=\left[\begin{array}{c}y \text { 圆 } \\ z \text { 圆 }\end{array}\right] \quad \Gamma_{0}=\left[\begin{array}{l}b_{10} \\ b_{20}\end{array}\right]$

$\Gamma_{1}=\left[\begin{array}{cc}1 & b_{12} \\ b_{21} & 1\end{array}\right] \quad \epsilon_{\mathrm{t}}=\left[\begin{array}{c}\epsilon y t \\ \epsilon z t\end{array}\right]$

The next step is by multiplying equation 6 to the inverse of $\mathrm{B}$, thus the equation transformed into:

$\chi_{\mathrm{t}}=\mathrm{B}^{-1} \Gamma_{0}+\mathrm{B}^{-1} \Gamma_{1} \chi_{t-1}+\mathrm{B}^{-1} \epsilon_{\mathrm{t}}=A_{0}+A_{1} \chi_{\mathrm{t}-1}+e_{\mathrm{t}}$

Finally, equation 7 is accepted as the VAR standard model. The estimation process, the VAR model includes lag element of a variable. Therefore, after considering the lag element, VAR model with lag element of $\mathrm{p}$ can be formulated as follows:

$\mathrm{X}_{\mathrm{t}}=\mathrm{A}_{0}+\mathrm{A}_{1} \mathrm{Xt}_{\mathrm{t}-1}+\mathrm{A}_{2} \mathrm{Xt}_{\mathrm{t}-2}+\ldots . .+\mathrm{A}_{\mathrm{p}} \mathrm{X}_{\mathrm{t}-\mathrm{p}}+\mathrm{e}_{\mathrm{t}}$

where:

$\mathrm{X}_{\mathrm{t}} \quad=$ vector $(\mathrm{n} \times 1)$ of the variables of $\mathrm{n}$ collected in VAR model;

$\mathrm{A}_{0} \quad=$ vector $(\mathrm{n} \times 1)$ of exogenous variable, which consist of constant value (intercept) and trend;

$\mathrm{A}_{1}=$ coefficient matrix with $(\mathrm{n} \times \mathrm{n})$ dimension;

$\mathrm{E}_{\mathrm{t}} \quad=$ vector $(\mathrm{n} \times 1)$ of the error term.

In the equation 8 , the error term represent the combination of two shock period namely eyt and ezt. Both shock, which assumed as white noise that mean its residual value has 0 mean value, constant variant, and non-auto correlated series (Enders, 2004).

The advantage of VAR analysis are: (1) simple method, both endogenous and exogenous variable is easy to distinguish; (2) simple estimation, where OLS method can be applied in each equation 
separately; (3) the forecast result, which obtained using this method, in many cases has better result compared to complex simultaneous equations. Moreover, VAR analysis is a useful analysis tool, either to understand interrelationship of economics variables or in establishment of a structured economics model (Gujarati, 2004).

\section{Impulse Response Function (IRF)}

According to (Enders, 2004), IRF is an instrument that can be used to track the response of endogenous variables value in the current period and future period, when there is shock or changes in the current interference variable value. Mathematical illustration of IRF instrument is presented by the representation of vector moving average of VAR model. In order to obtain the vector moving average representation, the equation 13 should be formed from the transformation of the equations below:

$\mathrm{y}_{t}=a_{10}+\mathrm{a}_{11} \mathrm{y}_{\mathrm{t}-1}+\mathrm{a}_{12} \mathrm{z}_{\mathrm{t}-1}+\mathrm{e}_{1 \mathrm{t}}$

$\mathrm{z}_{\mathrm{t}}=\mathrm{a}_{20}+\mathrm{a}_{21} \mathrm{y}_{\mathrm{t}-1}+\mathrm{a}_{22} \mathrm{z}_{\mathrm{t}-1}+\mathrm{e}_{2 \mathrm{t}}$

In the equation $9 \mathrm{a}$ and $9 \mathrm{~b}$, the term $a_{i o}$ is defined as the $\mathrm{i}$ element of the vector of $A_{l}, a_{i j}$ is defined as the element of line $\mathrm{i}$ and column of $\mathrm{j}$ of the matrix $\mathrm{A}$, and $e_{i t}$ is defined as the i element of vector $e_{t}$.

The next step to obtain the representation of vector moving average from the VAR model is by transforming the equation of $9 \mathrm{a}$ and $9 \mathrm{~b}$ in matrix notation, thus an equation 10 is obtained as follows:

$\left[\begin{array}{l}Y t \\ Z t\end{array}\right]=\left[\begin{array}{l}a 10 \\ a 20\end{array}\right]+\left[\begin{array}{ll}a 11 & a 12 \\ a 21 & a 22\end{array}\right]\left[\begin{array}{l}Y t-1 \\ z t-1\end{array}\right]+\left[\begin{array}{l}e 1 t \\ e 2 t\end{array}\right]$

By assuming that equation 10 has fulfilled stability test, thus the equation can be transformed into more solid equation as follows:

$\left[\begin{array}{l}Y t \\ z t\end{array}\right]=\left[\begin{array}{l}y \\ z\end{array}\right]+\sum_{i-0}^{\infty} \quad\left[\begin{array}{ll}a 11 & a 12 \\ a 21 & a 22\end{array}\right]+\left[\begin{array}{l}e 1 t-1 \\ e 2 t-1\end{array}\right]$

The error term of equation 11 is translated in the following form:

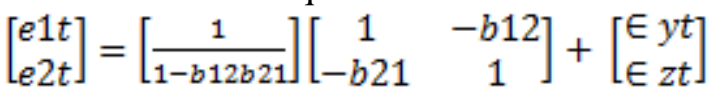

After the error term is translated, thus the last step is by combining the equation 11 and equation 12. Therefore, the representation of vector moving average from the VAR model is as follows:

$\left[\begin{array}{c}Y t \\ Z t\end{array}\right]=\left[\begin{array}{l}y \\ z\end{array}\right]+\left[\frac{1}{1-b 12 b 21}\right] \sum_{i-0}^{\infty} \quad\left[\begin{array}{ll}a 11 & a 12 \\ a 21 & a 22\end{array}\right]\left[\begin{array}{cc}1 & -b 12 \\ -b 21 & 1\end{array}\right]+\left[\begin{array}{l}E y t \\ \in \\ z t\end{array}\right] \ldots$

To simplify the equation 13, a notation of $\phi i$ can be used. In this term, the notation of $\phi i$ is defined as a matrix of $2 \times 2$, which include the element of $\phi_{j \mathrm{k}}(\mathrm{i})$. Mathematically, the notation of $\phi_{\mathrm{i}}$ can be translated as follows:

$\emptyset=\left[\frac{\Lambda_{1}^{i}}{1-b 12 b 21}\right]\left[\begin{array}{cc}1 & -b 12 \\ -b 21 & 1\end{array}\right]$

The simplification of vector moving average form in equation 13 by involved the notation of $\phi$ as translated in equation 14, generates the following equation:

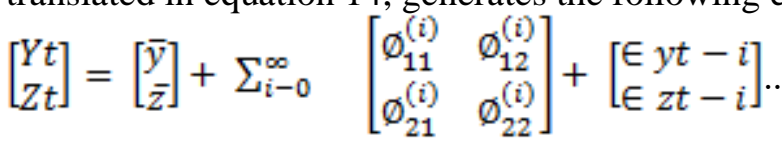

Finally, the equation of 15 is the final representation of vector moving average from the VAR model. In the equation 15, the IRF of VAR model is represented by 4 coefficients unit, namely $\phi 11(i), \phi_{12}(i), \phi_{21}(i)$, and $\phi_{22}(i)$.

\section{Forecasting Error Variance Decomposition}

A method that can be used to examine the changes in a variable, which represented by the changes in its variance of error, that affected by other variables is Forecast Error Decomposition of Variance (FEDV). FEDV is conducted to see the relative contribution of a variable in explaining its endogenous variable variability. This method can characterize the dynamic structures in VAR model. By using this method the power and weakness of each variable in affecting other variables in a long-term can be calculated.

Unit Root Test 
Unit Root Test can be viewed as stationary test, because the objective of the test is to examine whether certain coefficient in an autoregressive model has the value of one or not (Thomas, 1997). Unit root tests can be performed by estimating the following autoregressive models with the OLS method, which known as DF test (Dickey-Fuller) and ADF test (Augmented Dickey-Fuller):

$\mathrm{DX}_{\mathrm{t}}=\mathrm{a}_{0}+\mathrm{a}_{1} \mathrm{BX}_{\mathrm{t}}+\sum \mathrm{b}_{\mathrm{t}} \mathrm{B}_{\mathrm{t}} \mathrm{DX}_{\mathrm{t}}$

$\mathrm{DX}_{\mathrm{t}}=\mathrm{c}_{0}+\mathrm{c}_{1} \mathrm{~T}+\mathrm{c}_{2} \mathrm{BX}_{\mathrm{t}=\uparrow} \sum \mathrm{dt}_{\mathrm{t}} \mathrm{B}_{\mathrm{t}} \mathrm{DX}$

where; $\mathrm{DX}=\mathrm{X}_{\mathrm{t}}-\mathrm{X}_{\mathrm{t}-1}, \mathrm{BX} \stackrel{\mathrm{t}=1}{=} \mathrm{X}_{\mathrm{t}-1}, \mathrm{~T}=$ the trend of time; and $\mathrm{Xt}$ is the variable observed during the period of $\mathrm{t}$ while $\mathrm{B}$ is the backward lag operator.

The DF and ADF value, after calculated, that used in hypothesis test $\left(\mathrm{a}_{1}=0\right.$ and $\left.\mathrm{c}_{2}=0\right)$ is represented by the ratio of $\mathrm{t}$ in the regression coefficient of $\mathrm{BXt}$ in equation 17. The lag value of $\mathrm{k}$ is determined by $\mathrm{k}=\mathrm{N}_{1 / 3}$, where $\mathrm{N}$ is the quantity of observation. If the regression coefficient of $\mathrm{a}_{1}$ and $\mathrm{c}_{2}$ is not significant at a certain DF and ADF significance level, it can be concluded that the data observed is not stationary and must be continued with integration degree test until stationary data is obtained.

\section{Integration degree test}

The integration degree test is performed if the root test of the observed data unit is not stationary. This test is performed to know at what degree or order of differentiation the observed data is stationary. Time series data is said to be integrated to the degrees of $d$ or written as $I(d)$, if the data needs to be differentiated as much as d times to become a stationary data. Integration degree test is similar or is an extension of the unit root test, which can be performed using OLS.

\section{VAR model stability test}

The VAR model in optimum lag should be stable. Unstable VAR model will generate invalid result on the VAR model. The stability of VAR model can be identified using two methods. The first method is by identify the inverse roots characteristic of polynomial AR. In this method VAR method is considered stable if all values of the inverse roots have a modulus value that is lower than one. The second method is by identify the modulus value in a unit circle. A VAR model is considered stable if all of its modulus values are located within the unit-circle (Enders, 2004).

\section{Result and Discussion}

Stationary Test

The result of stationary test from the eight countries is presented in Table 5.

Table 5 Result of Stationary Test

\begin{tabular}{lc}
\hline & $\begin{array}{c}\text { Prob Augmented Dickey-Fuller test } \\
\text { statistic }\end{array}$ \\
& Lag Length: $0^{*}$ \\
\hline DJI & 0.4961 \\
ATHE & 0.8715 \\
JKSE & 0.4681 \\
STI & 0.5053 \\
SET & 0.3565 \\
KLSE & 0.5076 \\
VHINDEX & 0.1842 \\
AORD & 0.3250 \\
\hline
\end{tabular}

From the stationary test on the data in level or ordo $0[(0)]$ above, we can see the absolute statistic $\mathrm{ADF}(\mathrm{t} \alpha)$ value that is smaller than Mackinnon critical value in each $\alpha$, thus we can say that the data is not stationary. To find the degree of data integration, data integration test is needed (testing on the differentiation level) until there is stationary data in the same level. 


\section{Integration Level Testing}

The result of ADF testing on the eight stock price in ordo 1 [I(1)] can be seen in the following table.

Table 6. Result of Integration Level Testing

\begin{tabular}{cc} 
Stock price & Prob Augmented Dickey-Fuller test statistic \\
& Lag Length: 1 \\
\hline DJI & 0.0000 \\
ATHE & 0.0000 \\
JKSE & 0.0000 \\
STI & 0.0000 \\
SET & 0.0000 \\
KLSE & 0.0000 \\
VHINDEX & 0.0000 \\
AORD & 0.0000 \\
\hline
\end{tabular}

The result of stationary testing in the first differentiation level testing in all stock prices in this study is presented in the ordo 1 (one). The stationary testing result shows that all stationary data has significance level below 1 percent. This means that the stock price in US, Greece, Malaysia, Indonesia, Singapore, Thailand, Vietnam, and Australia is integrated in the first degree. This also means that all countries in this study have long term relationship. Further analysis is performed on the data that have been transformed into the first differentiation level.

\section{Determination of optimum lag}

The determination of optimum lag can be identified through Akaike Info Criterion (AIC), Schwarz Criterion (SC), and Hannan-Quinn Criterion (HQ).

Table 7. Optimum Lag Testing Result

\begin{tabular}{cccllll}
\hline Lag & LogL & LR & FPE & AIC & SC & HQ \\
\hline 0 & -18394.75 & NA & $6.50 \mathrm{e}+30$ & 93.65266 & 93.73356 & 93.68472 \\
1 & -14296.80 & 8008.214 & $7.90 \mathrm{e}+21$ & 73.12364 & $73.85167 *$ & 73.41215 \\
2 & -14147.75 & 285.2004 & $5.12 \mathrm{e}+21^{*}$ & $72.69083^{*}$ & 74.06599 & $73.23579^{*}$ \\
3 & -14096.70 & 95.59371 & $5.48 \mathrm{e}+21$ & 72.75676 & 74.77906 & 73.55817 \\
4 & -14066.59 & 55.17411 & $6.52 \mathrm{e}+21$ & 72.92920 & 75.59863 & 73.98706 \\
5 & -14027.80 & 69.48258 & $7.44 \mathrm{e}+21$ & 73.05751 & 76.37407 & 74.37182 \\
6 & -13978.18 & $86.87339^{*}$ & $8.03 \mathrm{e}+21$ & 73.13067 & 77.09437 & 74.70143 \\
7 & -13931.33 & 80.09759 & $8.82 \mathrm{e}+21$ & 73.21798 & 77.82881 & 75.04520 \\
8 & -13883.71 & 79.48712 & $9.67 \mathrm{e}+21$ & 73.30134 & 78.55931 & 75.38501 \\
\hline
\end{tabular}

Source: Result of Eviews 6 analysis

* indicates lag order selected by the criterion

The selection of optimum lag is performed through SC method developed by Canova (2003), which serves as better criteria because it gives higher level of penalty to the additional variable that reduce the degree of freedom. Based on the criteria, the candidate for optimum lag is selected according to its lag in which SC has the minimum or lag 1.

\section{VAR model stability testing}

The stability of VAR model can be identified based on two methods, first identify the value of inverse roots of polynomial AR characteristics and identify the modulus value in unit circle. 
Table 8. The Result of Polynomial Characters Model Stability Testing

\begin{tabular}{ll}
\hline \multicolumn{1}{c}{ Root } & Modulus \\
\hline 0.995783 & 0.995783 \\
0.987074 & 0.987074 \\
0.967662 & 0.967662 \\
$0.940859-0.030243 \mathrm{i}$ & 0.941345 \\
$0.940859+0.030243 \mathrm{i}$ & 0.941345 \\
0.910509 & 0.910509 \\
0.843789 & 0.843789 \\
0.134397 & 0.134397 \\
\hline
\end{tabular}

Source: Result of Eviews 6 analysis

No root lies outside the unit circle.

VAR satisfies the stability condition.

The result of the first model stability (Table 8) shows value under 1, this means VAR model is stable because all inverse-roots value have modulus lower than 1. In the Figure 1, we can also see that VAR model is stable because all modulus values are in the unit-circle.

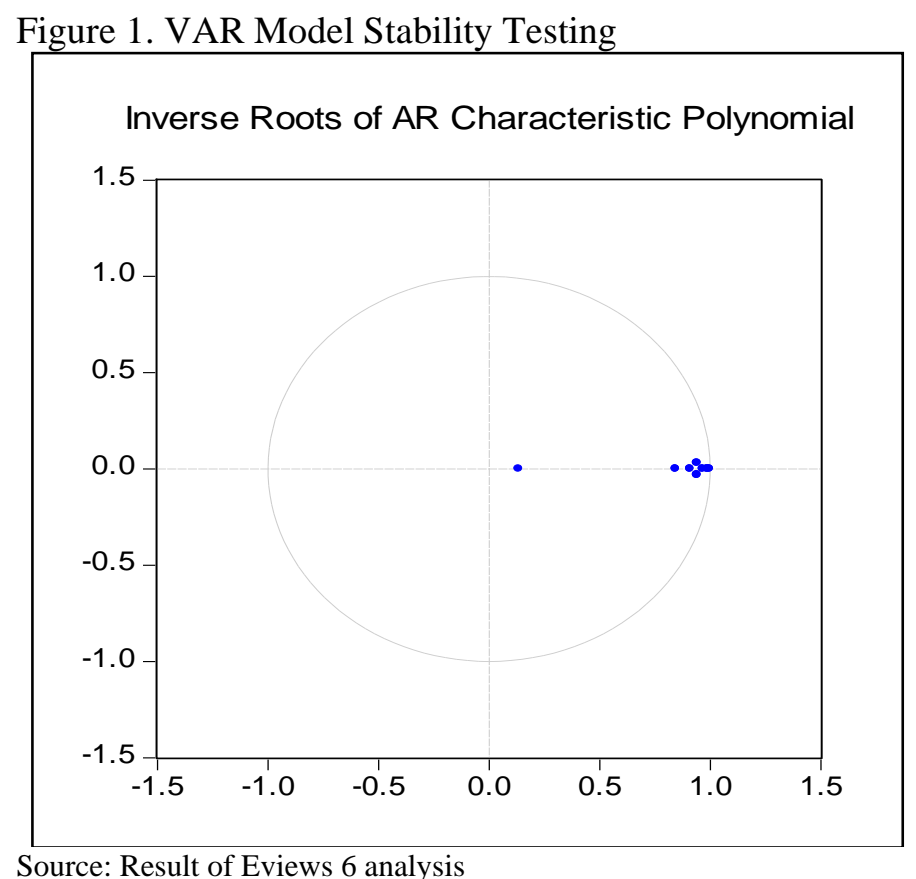

\section{FEDV Indonesia (JKSE) Analysis}

The variability of stock price in Indonesia on the stock price in ASEAN-4 and Australia can be explained in Table 9. We can see the composition of JKSE and stock price in ASEAN-4 and Australia in explaining the variability of stock price in Indonesia. In the first period, JKSE is the variable that has the strongest role in determining the variability of JKSE (100\%). The variability is decreasing in the tenth period, its effect reduced into 88.4 percent and contrary, the variability of stock index in other countries increases. We can observe that in Table 9, Malaysia (KLSE) has 2.65 percent effects in the tenth period, and most importantly Singapore (STI) has 6.73 percent of effect on the volatility in Indonesia. Other countries have less contribution on the existing volatility. 
Table 9. FEDV Analysis on Indonesian Composite Index (JKSE)

\begin{tabular}{ccccccc}
\hline \multicolumn{7}{c}{ Variance Decomposition of DJKSE: } \\
\hline Period & DJKSE & DKLSE & DSET & DSTI & DVHINDEX & DAORD \\
\hline 1 & 100 & 0 & 0 & 0 & 0 & 0 \\
2 & 98.700 & 0.212 & 0.814 & 0.018 & 0.058 & 0.194 \\
3 & 97.054 & 0.505 & 1.837 & 0.036 & 0.147 & 0.417 \\
4 & 95.483 & 0.812 & 2.802 & 0.048 & 0.249 & 0.603 \\
5 & 94.047 & 1.121 & 3.666 & 0.055 & 0.360 & 0.748 \\
6 & 92.739 & 1.428 & 4.435 & 0.058 & 0.478 & 0.859 \\
7 & 91.541 & 1.735 & 5.117 & 0.059 & 0.604 & 0.941 \\
8 & 90.437 & 2.041 & 5.722 & 0.059 & 0.738 & 1.000 \\
9 & 89.415 & 2.347 & 6.258 & 0.058 & 0.878 & 1.040 \\
10 & 88.462 & 2.653 & 6.733 & 0.058 & 1.025 & 1.066 \\
\hline
\end{tabular}

Source: Result of Eviews 6 analysis

\section{Conclusion and Suggestion}

Financial crisis in US (Dow Jones) affects or trigger a response (shocks) in ASEAN-5 and Australia. It also has a positive shock, except Vietnam which responds negatively. Financial crisis in Greece (ATHE) affects or trigger a response (shocks) in ASEAN-5 and Australia. This shock is positive, except in Indonesia in which the crisis receives negative response. Malaysia (KLSE) has 2.65 percent of effect in the tenth period and more importantly Singapore (STI) plays a role in the existing volatility with 6.73 percent. Other countries have less contribution in the volatility of Indonesian composite index (IHSG).

The annual growth of capital market can be considered high, all from go-public companies, number of investor who interested to invest their capital in the capital market, and various derivative products from capital market. Study on financial management regarding capital market and portfolio needs to be developed to provide operational standard for the parties that are active in the capital market. Generally, the government has to be careful on the crisis from other countries, because investor will react to it in timely manner. That is why the fundamental aspect of a country has to be strong in order to anticipate too high shocks.

\section{References}

Adamu, A. (2010), “The Effects Of Global Financial Crisis On Nigerian Economy”, Nasarawa State University.

Appleyard, D.R. and Jr, A.J.F. (1995), Internasional Economics, Second., Irwin, New York.

Bappenas, T.E.T. (2011), Krisis Keuangan Eropa: Dampak Terhadap Perekonomian Indonesia.

Bloomberg. (2011), “Ekonomi AS tersedot Gravitasi?”, Bloomberg Businessweek, September, pp. 18-19.

Canova, R. (2003), Three Essays on Updating Forecasts in Vector Autoregression Models, Canada.

Dash, A.K. and Mallick, H. (2010), "Contagion Effect of Global Financial Crisis on Stock Market in India”, JEL.

Enders, W. (2004), "Applied Econometric Time Series”, Wiley Series in Probability and Statistic, Second edi., John Wiley and Son, Inc, New York.

Gujarati, D.N. (2004), Basic Econometrics, Four Editi., McGraw-Hill International Edition, Singapore.

Kontan. (2011), "Krisis Utang AS Bisa Memicu Krisis Baru”, Kontan, 29 July, p. 1.

Krugman, P.R. and Obstfeld, M. (1999), Ekonomi Internasional: Teori Dan Kebijakan, Raja Grafindo Perkasa, Jakarta. Laeven, L. and Tong, H. (2010), U.S. Monetary Shocks and Global Stock Prices, No. WP/10/278.

Lensink, R., Hermes, N. and Murinde, V. (2000), "Capital Flight and Political Risk", The Journal of Internasional Money and Finance.

Mankiw, G.N. (2006), Pengantar Ekonomi Makro (Terjemahan), Ketiga., Salemba Empat, Jakarta.

Mishkin, F.S. (2007), The Economics of Money, Banking and Financial Market, 6th ed., Wesley, New York.

Prasetyantoko, A. (2008), "Bencana Finansial: Stabilitas Sebagai Barang Publik", Kompas Gramedia, Jakarta.

Salvatore, D. (1996), Internasioanal Economics, Prentice Hall Inc, New Jersey.

Schineller, L.M. (1997), “An Econometric Model of Capital Flight from Developing Countries”, Internasioanal Discussion Paper No. 594, Federal Reserve Board.

Thomas, R. (1997), Modern Econometrics: An Introduction, Eddison-Wesley, England.

Zhang, Z., Zhang, W. and Han, G. (2009), How Does The US Credit Crisis Affect The Asia-Pacific Economies? Analysis Based On A General Equilibrium Model, No. 12/2009. 